\title{
DYNAMIC ANALYSIS OF LAMINATED COMPOSITE PLATES
}

\author{
K. Maithry ${ }^{1}$, B D V Chandra Mohan Rao ${ }^{2}$ \\ ${ }^{I}$ M.Tech. (Structural Engg.) Student, VNR Vignana Jyothi Institute of Engg. \& Tech., Bachupally, Hyderabad - 500 \\ 090, kakanimaithry26@gmail.com \\ ${ }^{2}$ Professor of Civil Engg., VNR Vignana Jyothi Institute of Engg. \& Tech., Bachupally, Hyderabad - 500 090, \\ bdvcmrao@gmail.com
}

\section{SYNOPSIS}

In the recent years, the use of laminated composite plates has been increased considerably. Fiber reinforced composites are finding increasing applications in the aerospace, marine, transportation, electrical, chemical, construction and consumer goods industries. In many of these applications, the composites are often subjected to dynamic loads. Hence, the knowledge of dynamic behaviour of plates and shell structures is very essential for sound design. When such structures are subjected to dynamic loads, their behaviour is affected by excessive vibrations, higher displacements and accelerations which may deteriorate the structural performance. The dynamic response of laminated composite plates to excitations, varying arbitrarily with time is investigated in this paper.

The laminated composite structures may sometimes be provided with different types of holes for the purpose of assembling the components and units inside the structure, for passing the cables and control mechanisms, for inspection, maintenance and attachment to other units. Rectangular laminated plates fixed along the edges with holes at different positions are investigated by maintaining the same length / height ratio and hole area ratio for different fiber orientations. The modeling and dynamic analysis of the laminated plates has been carried out using ANSYS 13.0 software. The most robust fiber orientation with respect to various response parameters is suggested.

Keywords: Laminated Composite Plates, Dynamic loads, Fiber orientation, Deflection.

\section{INTRODUCTION}

Laminated composite plates are used especially in aerospace, naval structures, automobile industry and building construction in the form of prefabricated and mobile homes and floors made of plywood laminates. They are light in weight and possess high strength and hence they became very popular. Composites are a series of lamina or plies of varying thickness and/or materials. The lamina are stacked with various fibre orientations to obtain a laminate which has the desired directional stiffness and strength properties required for an acceptable design. Ply stacking sequence is important to obtain the stiffness and strength properties of an efficient laminate. In the design of plates and shell structures, weight reduction, limitation on natural frequencies, displacements and accelerations are aimed at structural improvement of cost, reliability and performance. In many practical situations, the dynamic excitation is neither harmonic nor periodic. Laminated composite plates subjected to static, transient dynamic loads are analyzed for thirteen varieties of fibre orientations $(0 / 0 / 0 / 0 / 0$, $0 / 30 / 45 / 30 / 0, \quad 0 / 30 / 0 / 30 / 0, \quad 0 / 45 / 0 / 45 / 0, \quad 45 / 0 / 45 / 0 / 45$, $45 / 0 / 0 / 0 / 45, \quad 45 /-45 / 0 /-45 / 45,30 / 60 / 90 / 60 / 30,30 /-45 / 0 /-$ 45/30, 90/45/0/45/90, 90/-60/45/-60/90, 90/0/90/0/90, $0 / 90 / 0 / 90 / 0)$. Finite element modelling of the plates is carried out using layered shell element in ANSYS 13.0 software.

\section{LITERATURE REVIEW}

A vibration analysis was carried out of symmetric angle-ply laminated composite plates with and without square hole when subjected to compressive loads, by Bahi-Eddine Lahouel and Mohamed Guenfoud ${ }^{1}$. Buckling analysis is also performed to determine the buckling load of laminated plates. The results showed that the presence of a constant compressive load tends to reduce uniformly the natural frequencies for materials which have a low degree of orthotropy.

Static and Dynamic analysis of Graphite /Epoxy composite plates under transverse loading using an eight-node disoparametric quadratic element based on First Order Shear Deformation Theory was studied by Junaid Kameran Ahmed, V.C. Agarwal, P.Pal, Vikas Srivastav². The minimum deflection was found at an angle of 15 degree for clamped plate, and in case of simply supported plate the minimum deflection was found for angle 45 degree.

Pathak et al. ${ }^{3}$ studied the transient dynamic analysis of three dimensional composite laminated plates. Simply supported plate made up of five layers, two orthotropic materials stacked in alternate layers are investigated. Number of plates are analyzed by varying the fiber orientation, thickness and type of loading.

A four-node laminated plate element is newly developed by using a higher order shear deformation theory (HSDT) by Sang Jin Lee; Ha Ryong $\mathrm{Kim}^{4}$. Assumed natural strains are introduced in the FE formulation to alleviate the locking phenomenon. It is found to be that the proposed FE is very 
effective to remove the locking phenomenon and produces reliable numerical solutions for most laminated composite plate structures.

Free vibration analysis of four layered angle-ply symmetric laminated plates with various lamination angles $\left( \pm 0^{\circ}\right.$ to $\left.\pm 90^{\circ}\right) \mathrm{s}$ of laminas with different hole locations were presented by Syed Altaf Hussain, V. Pandurangadu , K. Palani Kumar ${ }^{5}$. From the analysis it is inferred that the fundamental frequency of laminated composite plates decreases with increase in $\mathrm{L} / \mathrm{h}$ ratio.

\section{NUMERICAL STUDY}

A rectangular laminated plate of size $3 \mathrm{~m} \times 2 \mathrm{~m}$ fixed along all the four edges is investigated in this paper. Finite element modelling of the plates is carried out using layered shell element and is shown in Figure-1. The plate has been discretized into 1204 elements and 1276 nodes. The plate consists of five layers and the thickness of each layer is 4 $\mathrm{mm}$. Uniform pressure of $1000 \mathrm{~N} / \mathrm{m}^{2}$ is applied on the plate and the diameter of hole is kept as $0.5 \mathrm{~m}$. Two types of dynamic loads such as triangular impulsive type as shown in Figure-2(a) and rectangular impulsive type as shown in Figure-2(b) are applied on the plate. The peak load at each node is $10 \mathrm{~N}$ and load duration is one second in both the load cases 1,2. Laminated composite plates subjected to static, modal, transient dynamic loads are analyzed for 13 varieties of fiber orientations as shown in Figure-3.

Laminates are considered to be made of two orthotropic materials and joined alternatively to make full plate. First, Third, Fifth layers are made of material 1 and second, fourth layers are made of material 2 . The mechanical properties of these materials are as shown below.

\begin{tabular}{|c|c|c|c|}
\hline S.No. & Property & $\begin{array}{l}\text { Material - } \\
1\end{array}$ & $\begin{array}{l}\text { Material - } \\
2\end{array}$ \\
\hline 1 & $\begin{array}{l}\text { Longitudinal } \\
\text { Elasticity modulus, } \\
\mathrm{E}_{11}\end{array}$ & $\begin{array}{l}155 \times 10^{9} \\
\mathrm{~N} / \mathrm{m}^{2}\end{array}$ & $\begin{array}{l}50 \quad \times 10^{9} \\
\mathrm{~N} / \mathrm{m}^{2}\end{array}$ \\
\hline 2 & $\begin{array}{l}\text { Transverse } \\
\text { Elasticity modulus, } \\
\mathrm{E}_{22}\end{array}$ & $\begin{array}{l}12.1 \times 10^{9} \\
\mathrm{~N} / \mathrm{m}^{2}\end{array}$ & $\begin{array}{l}15.2 \times 10^{9} \\
\mathrm{~N} / \mathrm{m}^{2}\end{array}$ \\
\hline 3 & $\begin{array}{l}\text { Longitudinal } \\
\text { Elasticity modulus, } \\
\mathrm{E}_{33}\end{array}$ & $\begin{array}{l}12.1 \times 10^{9} \\
\mathrm{~N} / \mathrm{m}^{2}\end{array}$ & $\begin{array}{l}15.2 \times 10^{9} \\
\mathrm{~N} / \mathrm{m}^{2}\end{array}$ \\
\hline 4 & $\begin{array}{ll}\text { In-plane } & \text { Poisson's } \\
\text { ratio, } \mu_{12} & \end{array}$ & 0.458 & 0.428 \\
\hline 5 & $\begin{array}{l}\text { Transverse } \\
\text { Poisson's ratio, } \mu_{23}\end{array}$ & 0.248 & 0.254 \\
\hline 6 & $\begin{array}{ll}\text { In-plane } & \text { Poisson's } \\
\text { ratio, } \mu_{31} & \\
\end{array}$ & 0.248 & 0.254 \\
\hline 7 & $\begin{array}{ll}\text { In-plane } & \text { shear } \\
\text { modulus, } \mathrm{G}_{12} & \\
\end{array}$ & $\begin{array}{l}3.2 \times 10^{9} \\
\mathrm{~N} / \mathrm{m}^{2}\end{array}$ & $\begin{array}{l}3.28 \times 10^{9} \\
\mathrm{~N} / \mathrm{m}^{2}\end{array}$ \\
\hline 8 & $\begin{array}{ll}\text { Transverse } & \text { shear } \\
\text { modulus, } \mathrm{G}_{23} & \\
\end{array}$ & $\begin{array}{l}4.4 \times 10^{9} \\
\mathrm{~N} / \mathrm{m}^{2}\end{array}$ & $\begin{array}{l}4.7 \times 10^{9} \\
\mathrm{~N} / \mathrm{m}^{2}\end{array}$ \\
\hline 9 & $\begin{array}{ll}\text { Transverse } & \text { shear } \\
\text { modulus, } \mathrm{G}_{31} & \\
\end{array}$ & $\begin{array}{l}4.4 \text { X } 10^{9} \\
\mathrm{~N} / \mathrm{m}^{2}\end{array}$ & $\begin{array}{l}4.7 \times 10^{9} \\
\mathrm{~N} / \mathrm{m}^{2}\end{array}$ \\
\hline 10 & Density & $2200 \mathrm{~kg} / \mathrm{m}^{3}$ & $2500 \mathrm{~kg} / \mathrm{m}^{3}$ \\
\hline
\end{tabular}

\section{RESULTS \& DISCUSSION}

\subsection{Static Analysis of Clamped Plate}

A rectangular laminated plate fixed along all the four edges is subjected to static load of $1000 \mathrm{~N} / \mathrm{m}^{2}$. The maximum response parameter for various fiber orientations are given in Table-1. For a clamped plate without hole, it is observed that the peak deflection is minimum in the case of $90 /-$ $60 / 45 /-60 / 90$ and maximum in case of $0 / 0 / 0 / 0 / 0$. It is observed that the peak deflection is minimum in the case of 0/90/0/90/0 and maximum in case of 90/-60/45/-60/90 for all the remaining cases.

\subsection{Modal Analysis of Clamped Plate}

Free vibration analysis is carried out on a rectangular laminated plate fixed along all the four edges. The maximum response parameter for various fiber orientations are given in Table-1. For a clamped plate without hole, it is observed that the frequency is minimum in the case of $0 / 0 / 0 / 0 / 0$ and maximum in case of $90 /-60 / 45 /-60 / 90$. It is observed that the frequency is minimum in the case of $90 /-$ $60 / 45 /-60 / 90$ and maximum in case of $0 / 90 / 0 / 90 / 0$ for all the remaining cases.

\subsection{Transient Analysis of Clamped Plate - Load}

\section{Case 1}

A rectangular laminated plate fixed along all the four edges is subjected to triangular impulsive load i.e. load case- 1 . The maximum response parameters for various fiber orientations are given in Table -2 .

For a clamped plate without hole, it is observed that the peak deflection, velocity are minimum in the case of 90/$60 /-45 / 60 / 90$ and 90/45/0/45/90 respectively and maximum in case of $0 / 0 / 0 / 0 / 0$. Hence, $90 /-60 /-45 / 60 / 90$ is the most robust orientation with respect to various response parameters.

For a clamped plate with hole at center, it is observed that the peak deflection, velocity are minimum in the case of 0/90/0//90/0 and maximum in case of 90/-60/-45/60/90. Hence, $0 / 90 / 0 / 90 / 0$ is the most robust orientation with respect to various response parameters.

For a clamped plate with two holes at interior, it is observed that the peak deflection, velocity are minimum in the case of 0/90/0/90/0 and maximum in case of 90/-60/45/-60/90 and $90 / 45 / 0 / 45 / 90$ respectively. Hence, $0 / 90 / 0 / 90 / 0$ is the most robust orientation with respect to various response parameters.

For a clamped plate with four holes at edges, it is observed that the peak deflection, velocity are minimum in the case of 0/90/0/90/0 and maximum in case of 90/-60/45/-60/90 and $90 / 45 / 0 / 45 / 90$ respectively. Hence, $0 / 90 / 0 / 90 / 0$ is the most robust orientation with respect to various response parameters. 


\subsection{Transient Analysis of Clamped Plate - Load} Case 2

A rectangular laminated plate fixed along all the four edges is subjected to rectangular impulsive load i.e. load case -2 . The maximum response parameters for various fiber orientations are given in Table -3 .

For a clamped plate without hole, it is observed that the peak deflection, velocity are minimum in the case of 90/$60 /-45 / 60 / 90$ and 90/0/90/0/90 respectively and maximum in case of $0 / 0 / 0 / 0 / 0$. Hence, $90 /-60 /-45 / 60 / 90$ is the most robust orientation with respect to various response parameters.

For a clamped plate with hole at center, it is observed that the peak deflection, velocity are minimum in the case of $0 / 90 / 0 / / 90 / 0$ and maximum in case of 90/-60/-45/60/90. Hence, $0 / 90 / 0 / 90 / 0$ is the most robust orientation with respect to various response parameters.

For a clamped plate with two holes at interior, it is observed that the peak deflection, velocity are minimum in the case of 0/90/0/90/0 and maximum in case of 90/-60/45/-60/90 and $90 / 0 / 90 / 0 / 90$ respectively. Hence, $0 / 90 / 0 / 90 / 0$ is the most robust orientation with respect to various response parameters.

For a clamped plate with four holes at edges, it is observed that the peak deflection, velocity are minimum in the case of $0 / 90 / 0 / 90 / 0$ and $0 / 30 / 45 / 30 / 0$ respectively and maximum in case of $90 /-60 / 45 /-60 / 90$ and $90 / 0 / 90 / 0 / 90$ respectively. Hence, $0 / 90 / 0 / 90 / 0$ is the most robust orientation with respect to various response parameters.

\section{CONCLUSIONS}

Laminated composite plates fixed along all the four edges subjected to triangular and rectangular impulsive loads are investigated for various types of fiber orientations. It is observed that fiber orientation plays a vital role.

$>$ By properly orienting the fibers in a laminated composite plates, the maximum deflections can be reduced to an extent of about $80 \%$.This implies considerable saving in material can be achieved by properly orienting the fibers.

It is observed that the peak deflection, velocity are minimum in 0/90/0/90/0 orientation (most of the cases) and maximum in 90/-60/45/-60/45 orientation. (most of the cases) Hence, $0 / 90 / 0 / 90 / 0$ is the most robust orientation with respect to various response parameters.

$>$ Design of composite laminated plates based on these studies will not only save the material but also evolve robust design.

\section{REFERENCES}

[1]. Bahi-Eddine Lahouel and Mohamed Guenfoud, "Comparative Analysis of Vibration between Laminated Composite Plates with and without Holes under Compressive Loads", World Academy of
Science, Engineering and Technology, V.7, June 2013.

[2]. Junaid Kameran Ahmed, V.C. Agarwal, P.Pal, Vikas Srivastav, "Static and Dynamic Analysis of Composite Laminated Plate", International Journal of Innovative Technology and Exploring Engineering (IJITEE) ISSN: 2278-3075, V.3, Issue-6, November 2013.

[3]. Pathak, K.K., Vipin Arora and Jain J.K., "Parametric optimization of composite laminated plates under dynamic loads", Journal of Structural Engineering, V.34, No.3, 2007, pp. 191-194.

[4]. Sang Jin Lee; Ha Ryong Kim, "FE Analysis of Laminated Composite Plates Using a Higher Order Shear Deformation Theory with Assumed Strains", Latin American Journal of Solids and Structures, Online version ISSN 1679-7825, V.10 No.3, May 2013.

[5]. Syed Altaf Hussain, V. Pandurangadu , K. Palani Kumar, "Vibration Analysis of Laminated Composite Plates with Holes", International Journal Of Engineering Sciences \& Research Technology(IJESRT), ISSN: 2277-9655, Hussain, V.3. No.7, July 2014.
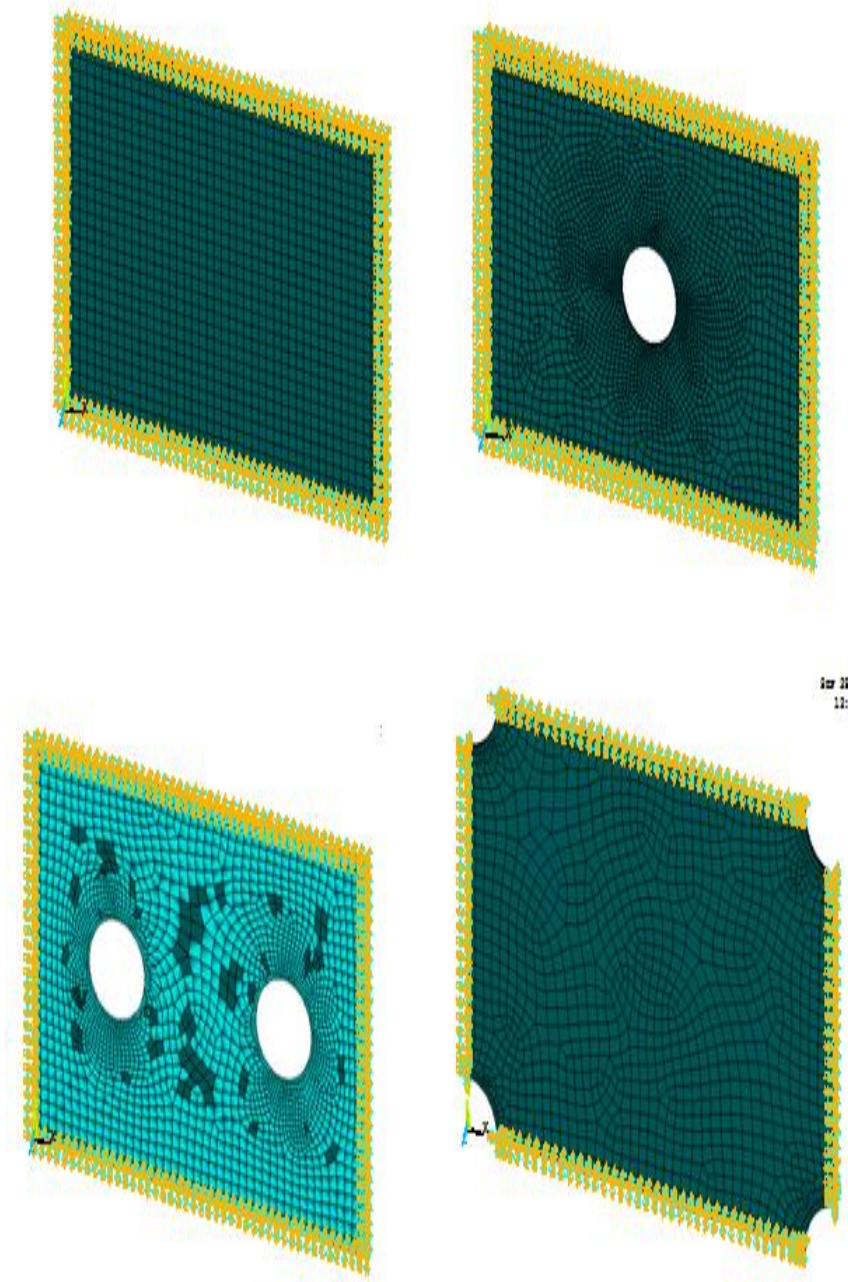

Figure 1: Finite Element Model of a Clamped Plate with Different Position of Holes 


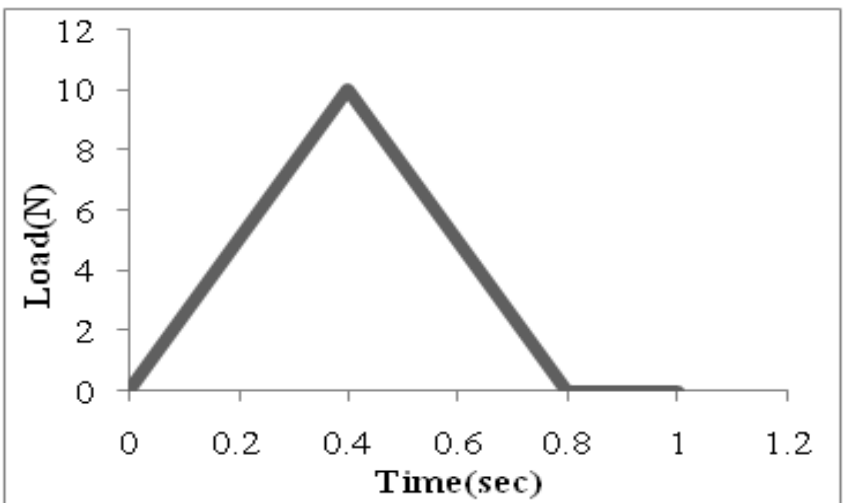

Figure 2(a): Triangular Impulsive Load Figure

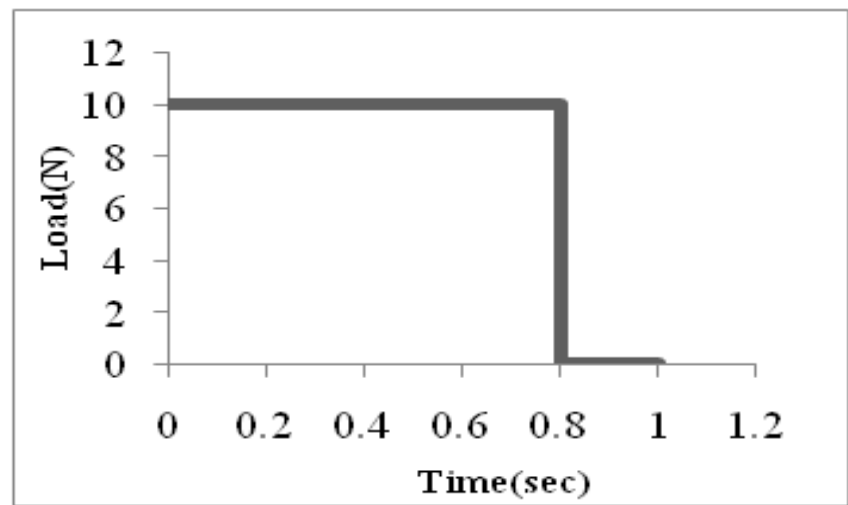

2(b): Rectangular Impulsive Load Load Case 1 Load Case2
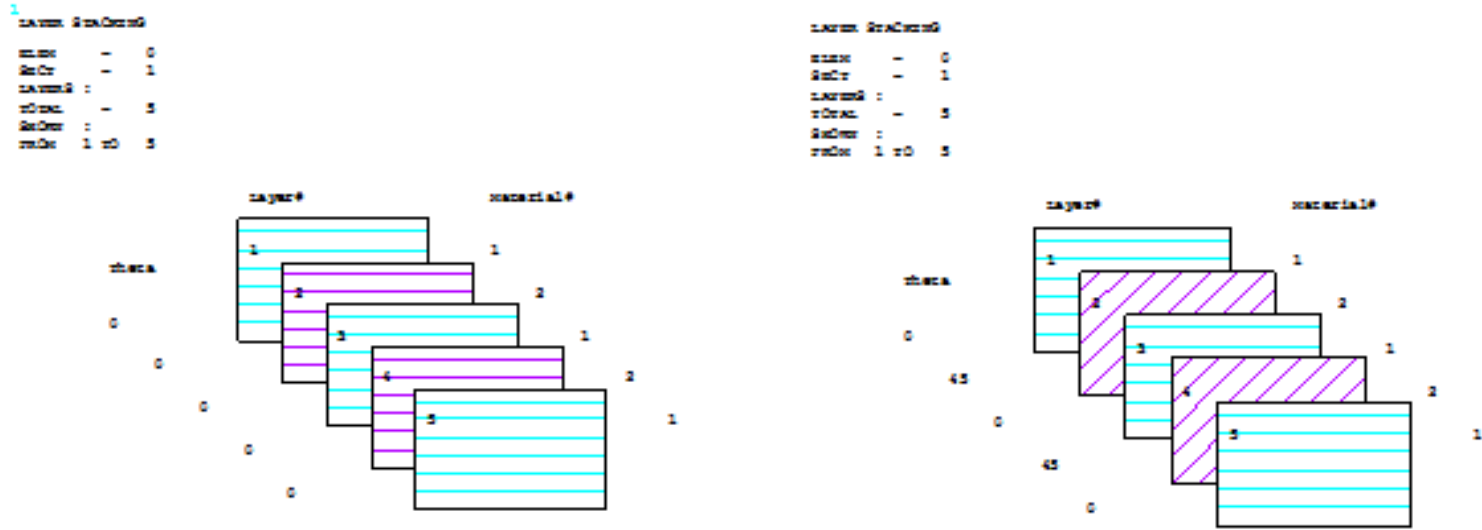

Figure 3: Fiber Orientations in a Laminated Composite Plate

Table 1: Static and Modal Responses of Clamped Plate

\begin{tabular}{|l|l|l|l|l|l|l|l|l|l|}
\hline \multirow{2}{*}{ S.No } & \multirow{2}{*}{ Fiber Orientation } & \multicolumn{6}{|l|}{ Static Analysis (Deflection in mm) } & \multicolumn{3}{|l|}{ Modal Analysis (Frequency in Hz) } \\
\cline { 3 - 10 } & & Without & $\begin{array}{l}\text { Hole } \\
\text { Hole } \\
\text { Center }\end{array}$ & $\begin{array}{l}\text { Two } \\
\text { Holes } \\
\text { at } \\
\text { Interior }\end{array}$ & $\begin{array}{l}\text { Four } \\
\text { Holes at } \\
\text { Edges }\end{array}$ & $\begin{array}{l}\text { Without } \\
\text { Hole }\end{array}$ & $\begin{array}{l}\text { Hole at } \\
\text { Center }\end{array}$ & $\begin{array}{l}\text { Two } \\
\text { Holes at Interior }\end{array}$ & $\begin{array}{l}\text { Four Holes } \\
\text { at Edges }\end{array}$ \\
\hline 1 & $0 / 0 / 0 / 0 / 0$ & 1.84 & 1.06 & 0.81 & 0.73 & 22.16 & 31.71 & 33.23 & 35.63 \\
\hline 2 & $0 / 30 / 45 / 30 / 0$ & 1.79 & 1.04 & 0.78 & 0.72 & 22.45 & 32.01 & 33.68 & 35.64 \\
\hline 3 & $0 / 30 / 0 / 30 / 0$ & 1.80 & 1.04 & 0.78 & 0.72 & 22.37 & 31.97 & 33.62 & 35.66 \\
\hline 4 & $45 / 0 / 45 / 0 / 45$ & 1.21 & 1.31 & 1.04 & 1.15 & 26.80 & 28.20 & 28.71 & 27.68 \\
\hline 5 & $45 / 0 / 0 / 0 / 45$ & 1.21 & 1.29 & 1.02 & 1.13 & 26.79 & 28.38 & 28.89 & 27.87 \\
\hline 6 & $45 /-45 / 0 /-45 / 45$ & 1.12 & 1.33 & 1.05 & 1.17 & 27.77 & 27.95 & 28.49 & 27.53 \\
\hline 7 & $30 / 60 / 90 / 60 / 30$ & 1.49 & 1.20 & 0.90 & 0.91 & 24.37 & 27.82 & 31.11 & 31.1 \\
\hline
\end{tabular}




\begin{tabular}{|l|l|l|l|l|l|l|l|l|l|}
8 & $30 /-45 / 0 /-45 / 30$ & 1.47 & 1.19 & 0.86 & 0.86 & 24.49 & 30.00 & 31.79 & 32.04 \\
\hline 9 & $90 / 45 / 0 / 45 / 90$ & 0.50 & 1.72 & 1.96 & 1.98 & 39.33 & 22.91 & 21.20 & 20.87 \\
\hline 10 & $90 /-60 / 45 /-60 / 90$ & 0.49 & 1.95 & 2.17 & 2.14 & 39.62 & 21.62 & 20.10 & 20.00 \\
\hline 11 & $90 / 0 / 90 / 0 / 90$ & 0.51 & 1.62 & 1.79 & 1.79 & 39.16 & 23.82 & 22.10 & 22.03 \\
\hline 12 & $0 / 90 / 0 / 90 / 0$ & 1.62 & 0.97 & 0.76 & 0.72 & 23.70 & 32.87 & 33.96 & 35.75 \\
\hline 13 & $0 / 45 / 0 / 45 / 0$ & 1.75 & 1.02 & 0.77 & 0.72 & 22.68 & 32.24 & 33.83 & 35.66 \\
\hline
\end{tabular}

Table 2: Maximum dynamic responses of Clamped Plate for Load Case-1

\begin{tabular}{|c|c|c|c|c|c|c|c|c|c|}
\hline \multirow{2}{*}{ S.No } & \multirow{2}{*}{$\begin{array}{l}\text { Fiber } \\
\text { Orientation }\end{array}$} & \multicolumn{2}{|c|}{ Without Hole } & \multicolumn{2}{|c|}{ Hole at Center } & \multicolumn{2}{|c|}{ Two Holes at Interior } & \multicolumn{2}{|c|}{ Four Holes at Edges } \\
\hline & & $\begin{array}{l}\text { Deflection } \\
(\mathrm{mm})\end{array}$ & $\begin{array}{l}\text { Velocity } \\
(\mathrm{mm} / \mathrm{sec})\end{array}$ & $\begin{array}{l}\text { Deflection } \\
(\mathbf{m m})\end{array}$ & $\begin{array}{l}\text { Velocity } \\
(\mathrm{mm} / \mathrm{sec})\end{array}$ & $\begin{array}{l}\text { Deflection } \\
(\mathrm{mm})\end{array}$ & $\begin{array}{l}\text { Velocity } \\
(\mathrm{mm} / \mathrm{sec})\end{array}$ & $\begin{array}{l}\text { Deflection } \\
(\mathrm{mm})\end{array}$ & $\begin{array}{l}\text { Velocity } \\
(\mathrm{mm} / \mathrm{sec})\end{array}$ \\
\hline 1 & $0 / 0 / 0 / 0 / 0$ & 3.74 & 15.40 & 8.25 & 30.50 & 3.15 & 10.03 & 1.38 & 4.99 \\
\hline 2 & $0 / 30 / 45 / 30 / 0$ & 3.63 & 14.80 & 8.08 & 29.9 & 3.07 & 9.74 & 1.37 & 4.96 \\
\hline 3 & $0 / 30 / 0 / 30 / 0$ & 3.67 & 15.00 & 8.10 & 29.99 & 3.08 & 9.77 & 1.37 & 4.96 \\
\hline 4 & $45 / 0 / 45 / 0 / 45$ & 2.44 & 9.62 & 10.95 & 41.74 & 4.7 & 17.98 & 2.11 & 8.41 \\
\hline 5 & $45 / 0 / 0 / 0 / 45$ & 2.45 & 9.64 & 10.80 & 41.08 & 4.63 & 24.48 & 2.09 & 8.27 \\
\hline 6 & $45 /-45 / 0 /-45 / 45$ & 2.24 & 8.97 & 11.05 & 42.38 & 4.81 & 16.64 & 2.12 & 8.47 \\
\hline 7 & $30 / 60 / 90 / 60 / 30$ & 3.02 & 12.28 & 10.01 & 38.97 & 3.78 & 12.79 & 1.72 & 6.56 \\
\hline 8 & $30 /-45 / 0 /-45 / 30$ & 2.99 & 13.44 & 9.83 & 36.79 & 3.58 & 11.99 & 1.60 & 6.12 \\
\hline 9 & $90 / 45 / 0 / 45 / 90$ & 1.01 & 3.77 & 13.26 & 50.83 & 7.13 & 48.51 & 3.73 & 36.64 \\
\hline 10 & $90 /-60 / 45 /-60 / 90$ & 0.99 & 5.02 & 15.20 & 77.43 & 7.71 & 30.98 & 3.95 & 17.26 \\
\hline 11 & $90 / 0 / 90 / 0 / 90$ & 1.03 & 3.83 & 12.34 & 48.76 & 6.56 & 25.38 & 3.38 & 13.87 \\
\hline 12 & 0/90/0/90/0 & 3.23 & 13.08 & 7.62 & 28.01 & 2.94 & 9.35 & 1.36 & 4.90 \\
\hline 13 & $0 / 45 / 0 / 45 / 0$ & 3.55 & 14.32 & 7.95 & 29.45 & 3.04 & 9.66 & 1.37 & 4.94 \\
\hline
\end{tabular}


Table 3: Maximum dynamic responses of Clamped Plate for Load Case-2

\begin{tabular}{|c|c|c|c|c|c|c|c|c|c|}
\hline \multirow{2}{*}{$\begin{array}{l}\text { S.N } \\
\text { o }\end{array}$} & \multirow{2}{*}{$\begin{array}{l}\text { Fiber } \\
\text { Orientation }\end{array}$} & \multicolumn{2}{|c|}{ Without Hole } & \multicolumn{2}{|c|}{ Hole At Center } & \multicolumn{2}{|c|}{$\begin{array}{l}\text { Two Holes } \\
\text { Interior }\end{array}$} & \multicolumn{2}{|c|}{ Four Holes At Edges } \\
\hline & & $\begin{array}{l}\text { Deflectio } \\
\text { n (mm) }\end{array}$ & $\begin{array}{l}\text { Velocity } \\
\text { (mm/sec } \\
\text { ) }\end{array}$ & $\begin{array}{l}\text { Deflectio } \\
\text { n (mm) }\end{array}$ & $\begin{array}{l}\text { Velocity } \\
\text { (mm/sec } \\
\text { ) }\end{array}$ & $\begin{array}{l}\text { Deflection } \\
(\mathrm{mm})\end{array}$ & $\begin{array}{l}\text { Velocity } \\
(\mathrm{mm} / \mathrm{sec})\end{array}$ & $\begin{array}{l}\text { Deflectio } \\
\mathbf{n}(\mathbf{m m})\end{array}$ & $\begin{array}{l}\text { Velocity } \\
\text { (mm/sec } \\
\text { ) }\end{array}$ \\
\hline 1 & $0 / 0 / 0 / 0 / 0$ & 7.45 & 906 & 17.72 & 2098 & 8.27 & 486 & 2.76 & 141 \\
\hline 2 & $0 / 30 / 45 / 30 / 0$ & 7.15 & 538 & 17.15 & 978 & 8.01 & 501 & 2.75 & 140 \\
\hline 3 & $0 / 30 / 0 / 30 / 0$ & 7.24 & 683 & 17.23 & 1038 & 8.03 & 513 & 2.75 & 143 \\
\hline 4 & $45 / 0 / 45 / 0 / 45$ & 4.87 & 280 & 21.90 & 1095 & 11.69 & 1321 & 4.40 & 216 \\
\hline 5 & $45 / 0 / 0 / 0 / 45$ & 4.88 & 287 & 21.59 & 1080 & 11.52 & 1349 & 4.33 & 212 \\
\hline 6 & $45 /-45 / 0 /-45 / 45$ & 4.67 & 227 & 21.90 & 1095 & 11.93 & 952 & 4.41 & 219 \\
\hline 7 & $30 / 60 / 90 / 60 / 30$ & 6.08 & 468 & 19.57 & 2157 & 9.88 & 513 & 3.54 & 259 \\
\hline 8 & $30 /-45 / 0 /-45 / 30$ & 5.92 & 440 & 18.85 & 943 & 9.63 & 482 & 3.33 & 175 \\
\hline 9 & $90 / 45 / 0 / 45 / 90$ & 2.39 & 223 & 22.82 & 1106 & 18.36 & 842 & 7.45 & 797 \\
\hline 10 & $\begin{array}{l}90 /-60 / 45 /- \\
60 / 90\end{array}$ & 2.33 & 275 & 26.23 & 2826 & 20.28 & 1068 & 8.16 & 362 \\
\hline 11 & 90/0/90/0/90 & 2.41 & 146 & 22.23 & 1618 & 17.53 & 2028 & 6.65 & 764 \\
\hline 12 & 0/90/0/90/0 & 6.28 & 304 & 16.11 & 806 & 7.77 & 403 & 2.72 & 149 \\
\hline 13 & $0 / 45 / 0 / 45 / 0$ & 6.89 & 471 & 16.89 & 897 & 7.90 & 452 & 2.74 & 141 \\
\hline
\end{tabular}

